Historic, Archive Document

Do not assume content reflects current scientific knowledge, policies, or practices. 



\section{St. Regis Everbearing Red Raspberries ${ }^{\$} 1.00$ AND}

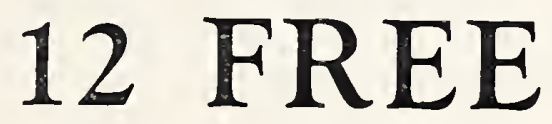

Year after year, in our August Pre-Season folders, we have given our customers the opportunity of securing 12 twoyear St. Regis Everbearing Red Raspberry bushes for $\$ 1.00$ with 12 free. And year after year the demand has far exceeded the supply. Don't delay sending in your order. Better do it today.

\section{ST. REGIS EVERBEARING RASPBERRIES $\$ 1.00$ and 12 FREE}

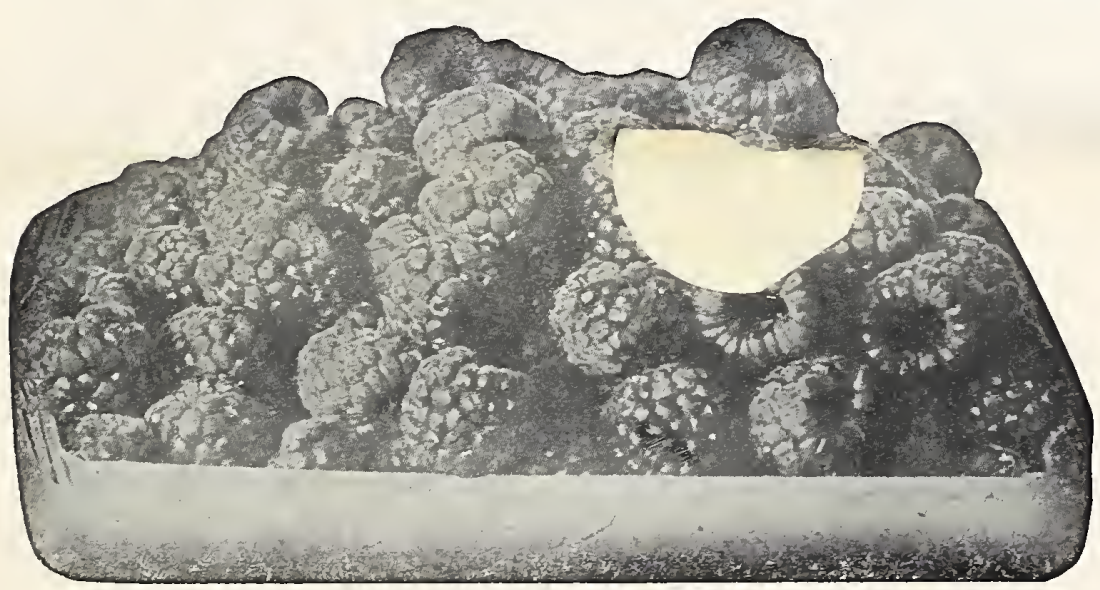

\section{CONCORD GRAPES}

There is little that has not been said about the merits of the Concord Grape. As a table grape it is delicious and for cooking it is unexcelled. If you will send us your order immediately we will mail you six two-year vines, parcel post, for only $\$ 1.00$.

6 Concord Grapes $\$ 1.00$

\section{CUMBERLAND RASPBERRIES 20 For $\$ 1.00$}

We have no other offer in this folder that is more truly an August Special than this-20 two-year Cumberland Raspberries, for only $\$ 1.00$. If you like the delicious and unusual flavor that the Cumberland Black Raspberries offer, you will surely want to order all you have room to plant. Think of the pleasure of raising your own berries--of being able to go out in the garden early in the morning to pick a bowlful of luscious Blackcaps for your breakfast. And think of receiving 20 of these fine bushes for only $\$ 1.00$.

\section{Cumberland Raspberries fOR ONLY $\$ 1.00$}

\section{August
re-Season \\ August
Pre-Season \\ Specials}

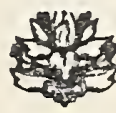

GROWERS' SALES CO.

CLINTON. N.J.
SEC. $4351 / 2$ P. L. \& R.

U. S. POSTAGE

PAID

CLINTON, N. J. PERMIIT No. 1

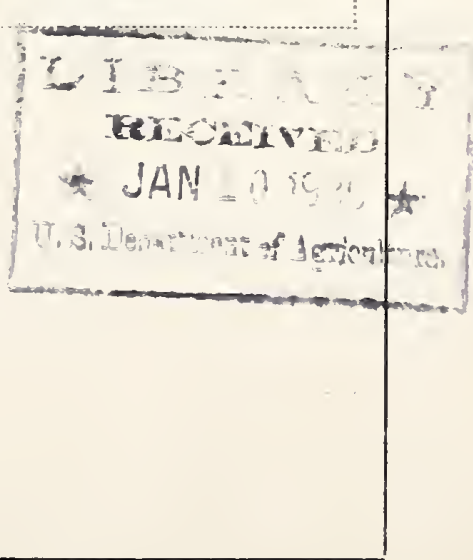





\section{Special Pre-Season Prices on Beautiful Floweroing Shroubs}

ALTHEA, ROSE OF SHARON

\section{4 for ${ }^{5}$ I. 00}

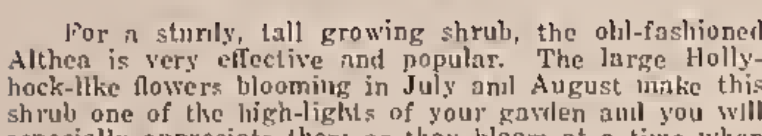

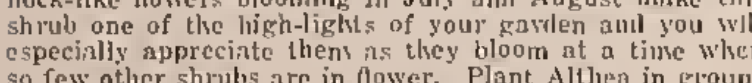
of three or four oll your linwn and holp to keep yisur Illace
blive iluring the warn summer days. Every plant is

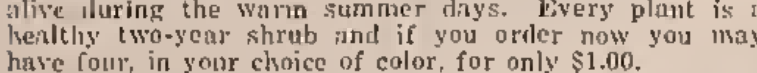

RLI, WHITE, PINK, PURPLLE:

4 ALTHEA

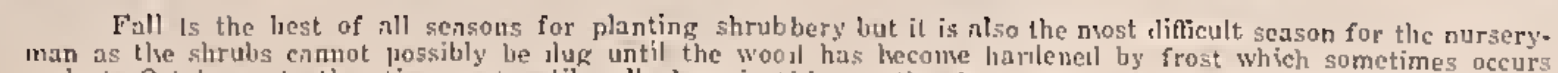

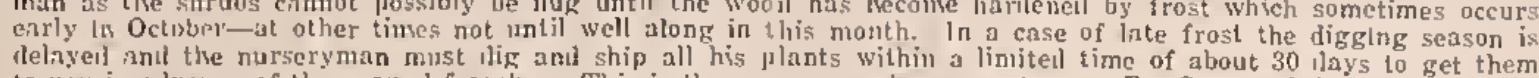

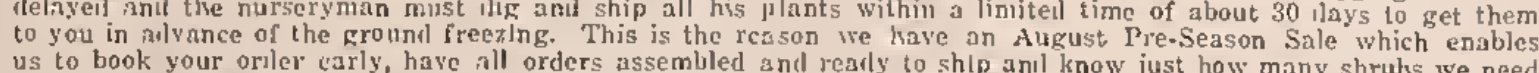

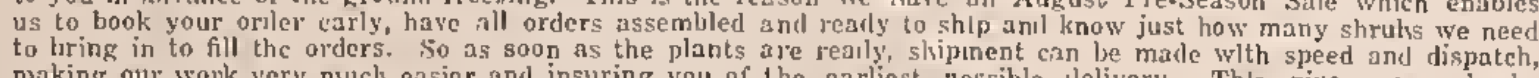

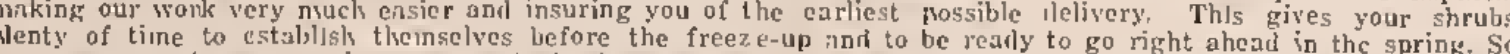
you cin see ortitering now is to linir nutual advantage ant to minke it evell more to your allvantage to order

PURPLE LILAC

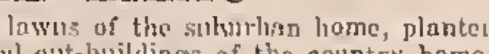

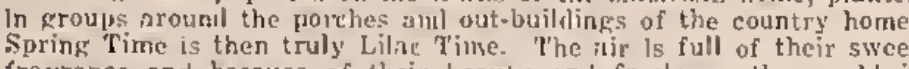

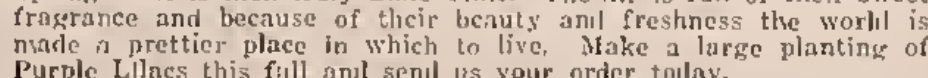
$37 \mathrm{c}$ Each-3 For $\$ 1.00$
BUSH HONEYSUCKLE

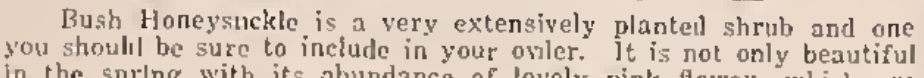

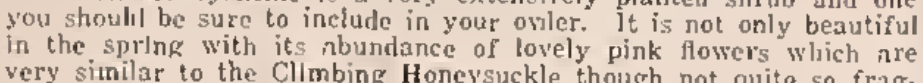

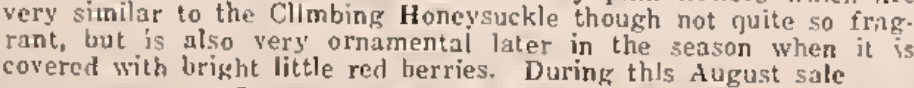
27c Each-4 For $\$ 1.00$

\section{HYDRANGEA P. G.}

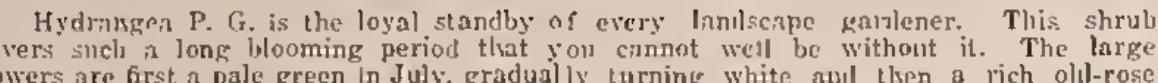

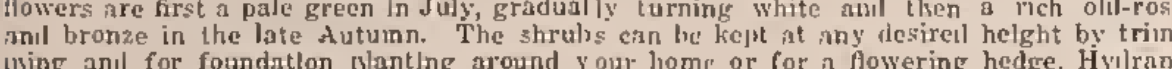
ea P. G. nimo is $75 \mathrm{c}$ each bue
plant. for only

$33 \mathrm{c}$ Each-4 For $\$ 1.19$

SNOWBERRY

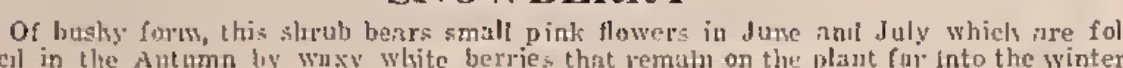

27c Each-4 For \$1.00

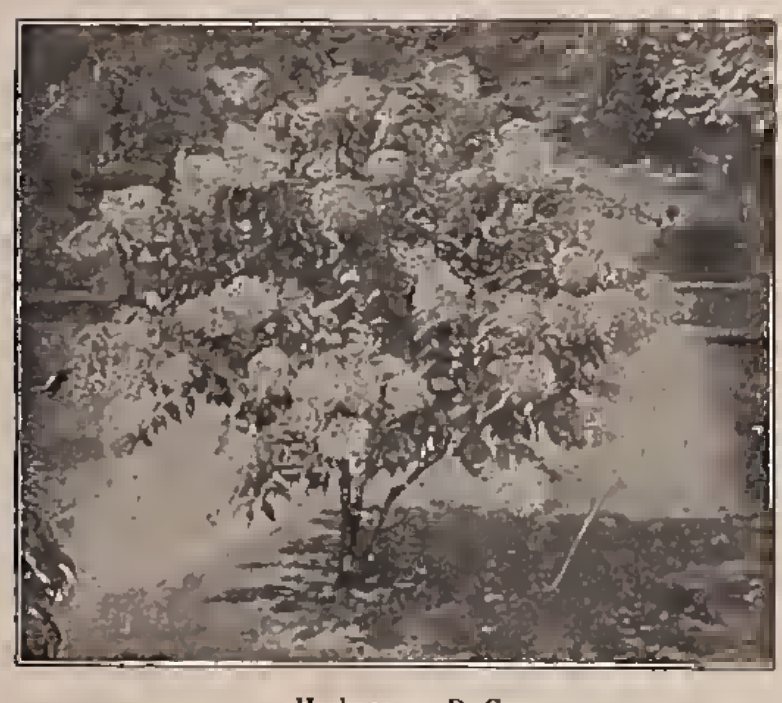

Hydrangea $P$, G.

Growers' Sales Co.

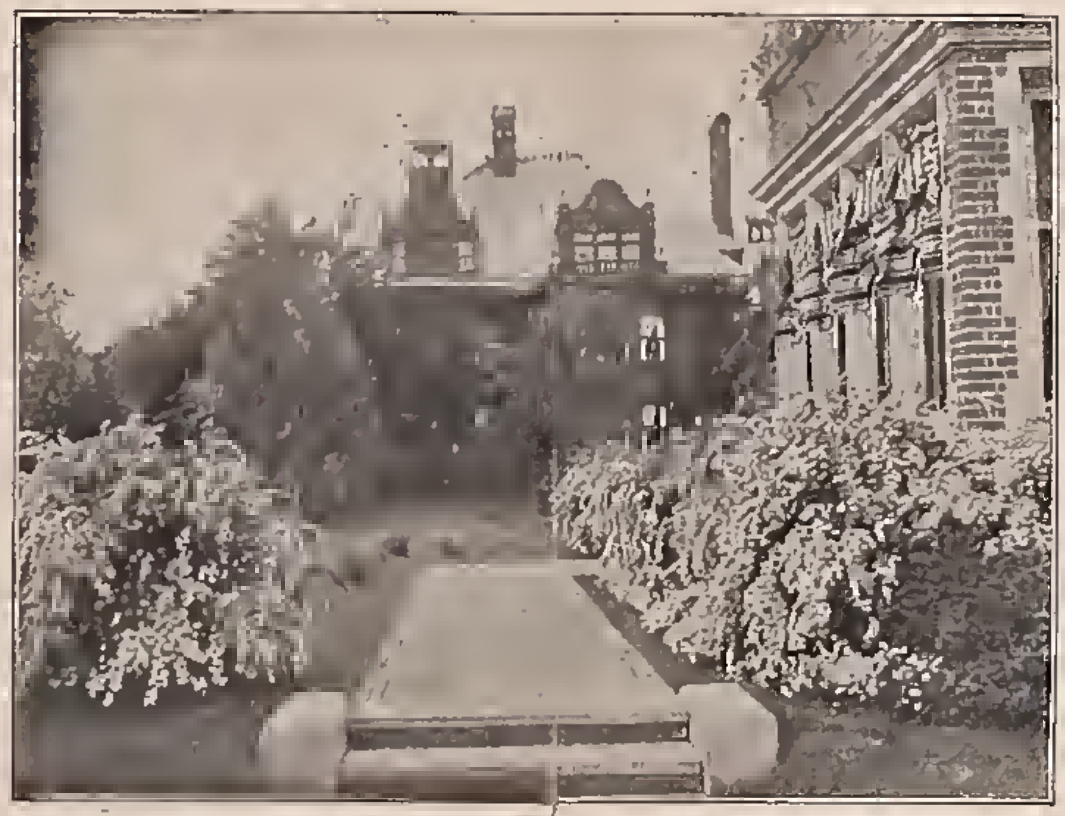

A Grous Planting of Spiren Yin Ilonltei

SPIREA VAN HOUTTEI

Spirea Van Houttei is withount a lloult the finest of all the Spirens. Coveresl with il wealth of snow-white blooms in Miny and June

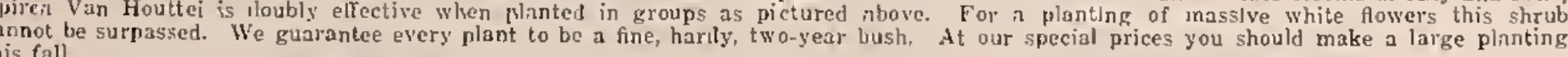

SNOWBALL

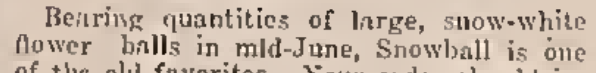

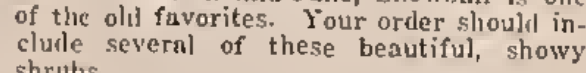

37c Each-3 For $\$ 1,00$
WEIGELA ROSEA When in hower In June, Weigela Rosea
is literally blanketed withl lovely rosese-rink blossoms that make this shrub one of thile
inost colorful of all the flowering varieties.

37c Each-3 For $\$ 1.00$
5 For Only $\$ 1.00$ DEUTZIA

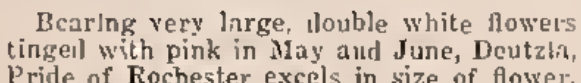

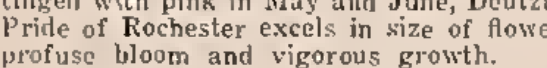
37c Each-3 For $\$ 1.00$

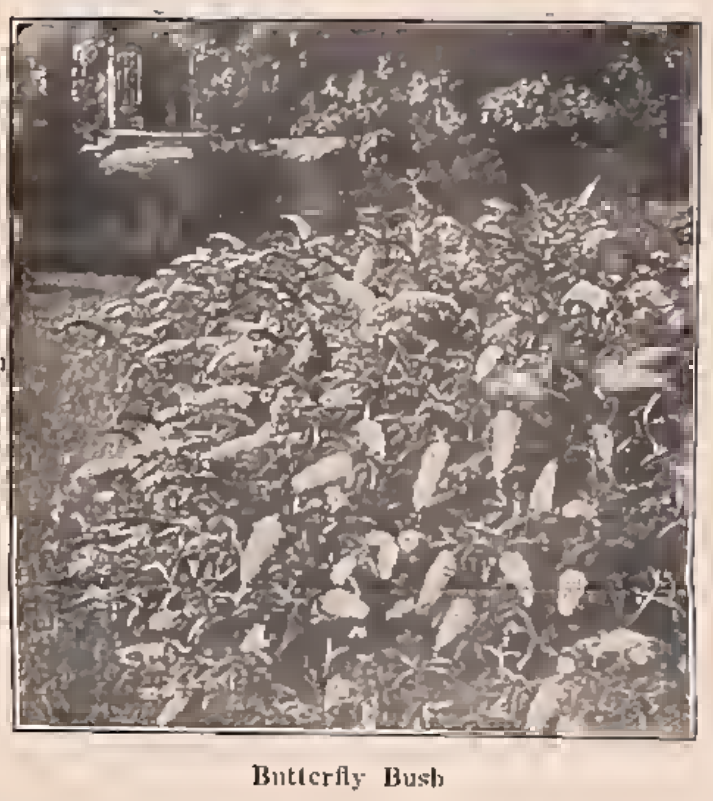

BUTWERPER BUSH

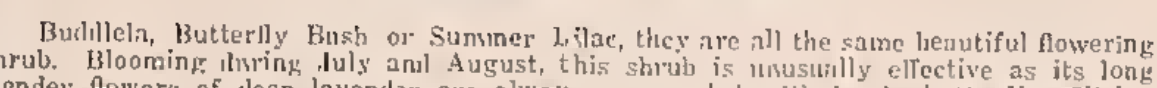

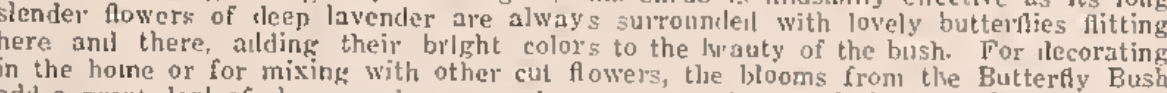

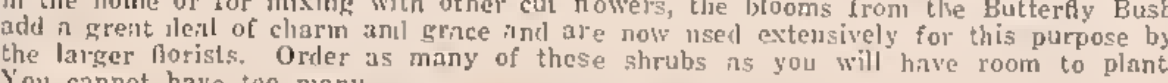

33 c Each-4 For $\$ 1.19$

FORSYTHIA

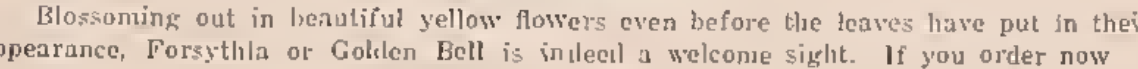
29 c Each-4 For $\$ 1.00$

Flowering Dogwood Flowering Dogwood is another of the popular and
beautitiul flowering shrubs. S Spot thein around your lawn in groups of two and three anil the wey will cheer and
hrighten your grounds with their lovely white blossoms when very few other lowers are in bloons; and the wood
which turns reel in the fall is ornansental the year rounit.

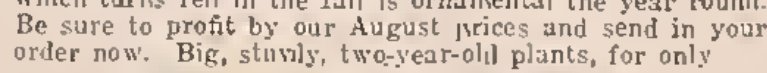

3 s.1. $\$$

Clinton, N. J. 



\section{Wholesale Prices on Retail Orders \\ If You Order 100 or More}

DARWIN TULIPS

IN SEPARATE COLORS

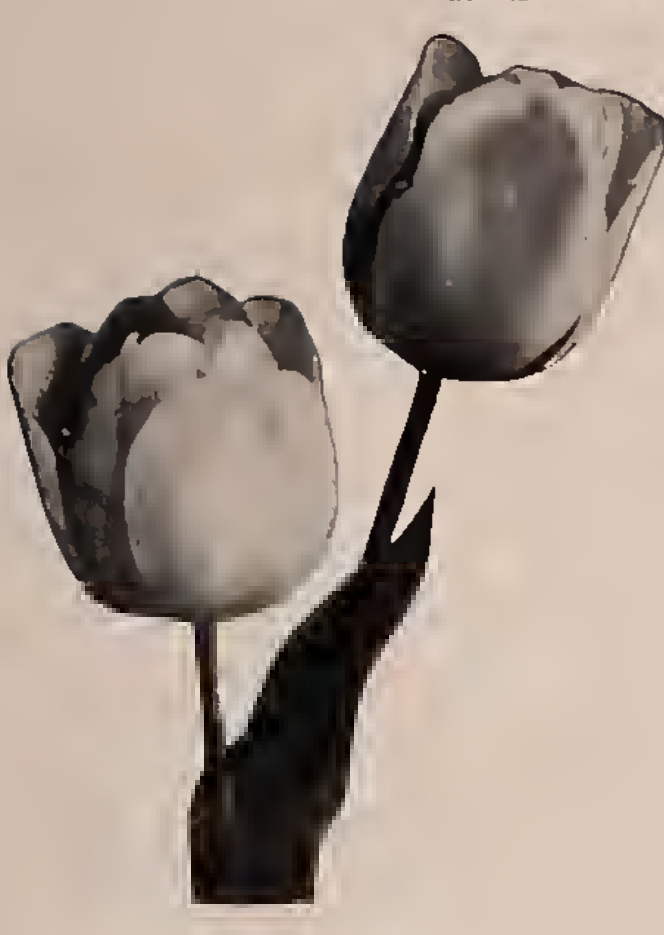

Darwin 'Tulips Tall anul regal in appcarnuce, benutiful in charnilng simplicity anl grace, the Darwins karilen. Delicate liveniler, obll-rose, snlmon-pink, with such colors as these youl can urrange match your honie next spring surromulecl with beils of theso tall Darwins, nodilng, tossing, swaying in well afforll to think uhont-a trean your can well Tering our lurge sized Darwins at quantity If you will send in your orler now you may have your elooice of the colors listed (in

44c PER DOZ \$3,49 PER 100 \$32.50 PER 1000
Lo Tulipe Noir Pride of Haarlem

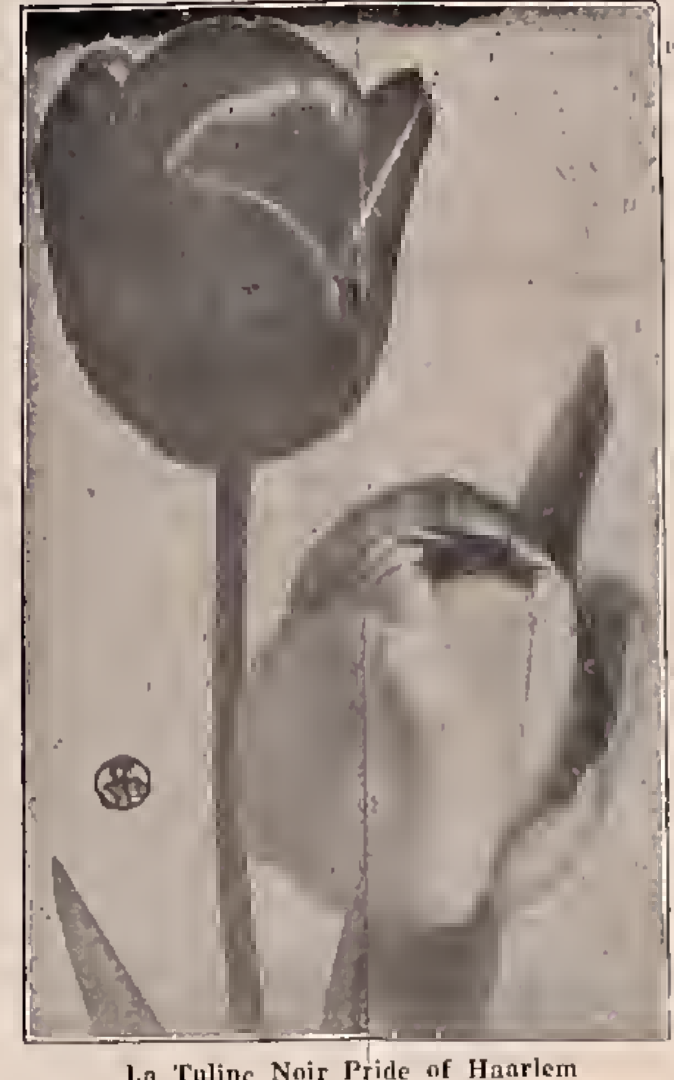

HARDY NARCISSUS

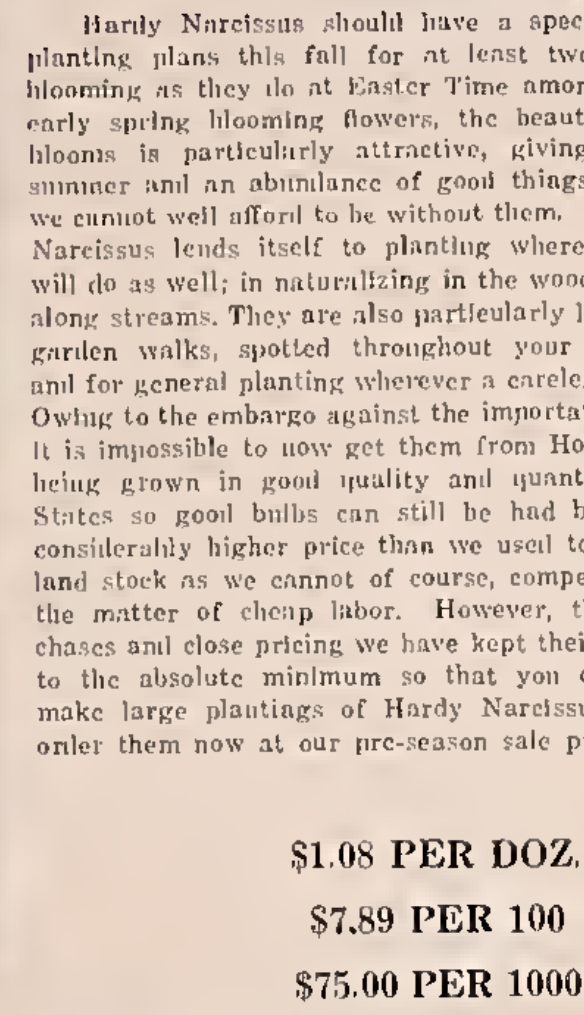

PRIDE OF HAARLEM

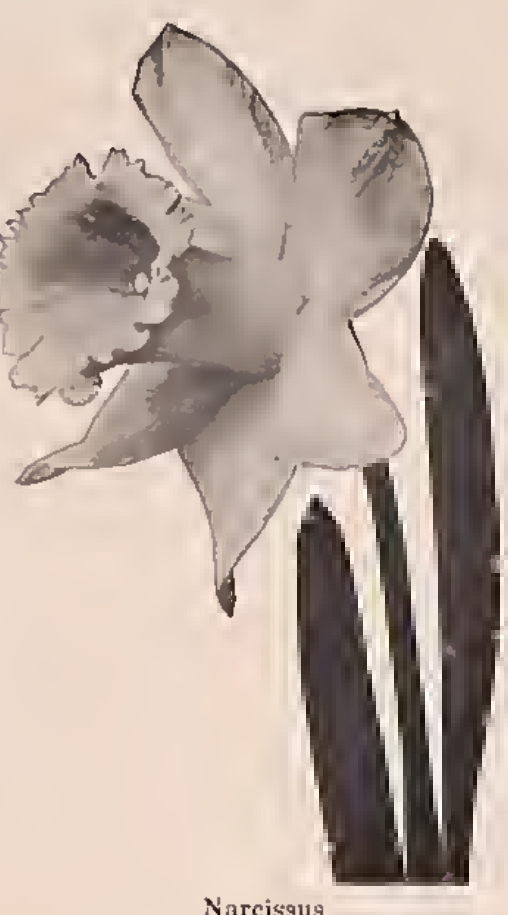

REMBRANDTS
BREEDERS

LA TULIPE NOIR

47c PER DOZ. hornell, toothed, twisted anll curved and brilliantly colorell wict shaded a decidet? old

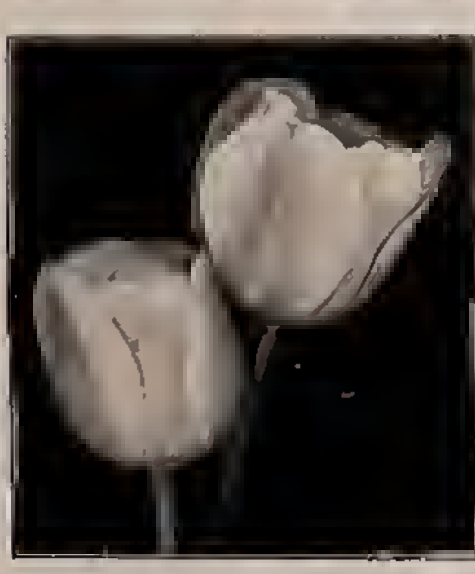

SIngle Tulips 47c PER DOZ

\$3.69 PER 100

\$3.69 PER 100

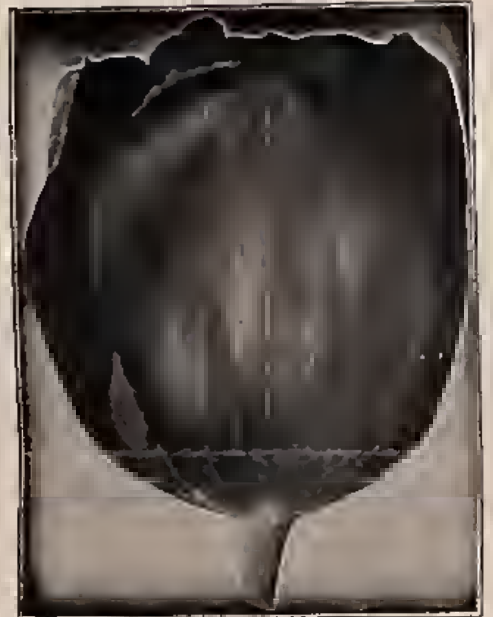

Brecder Tulip
THREE UNUSUAL TULIPS PARROT

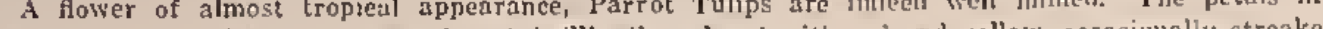

PICOTEE

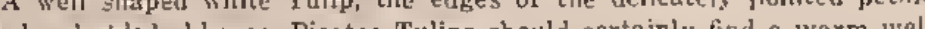

PEONY

Large anl double, blooming in scarlet or bright yellow, Peony Tulips re the showiest of all the Tulip varieties. For making a gorgeous display Peony Tulips cannot be equaled.

59c PER DOZ

$\$ 4.59$ PER 100

$\$ 42.50$ PER 1000

\section{EARLY SINGLE TULIPS}

Not only are the Early Singles the first Tulips to bloom but they

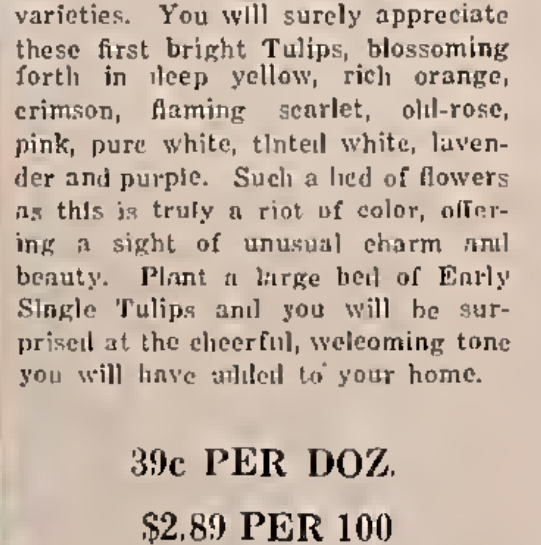

\$3.50 PER 1000

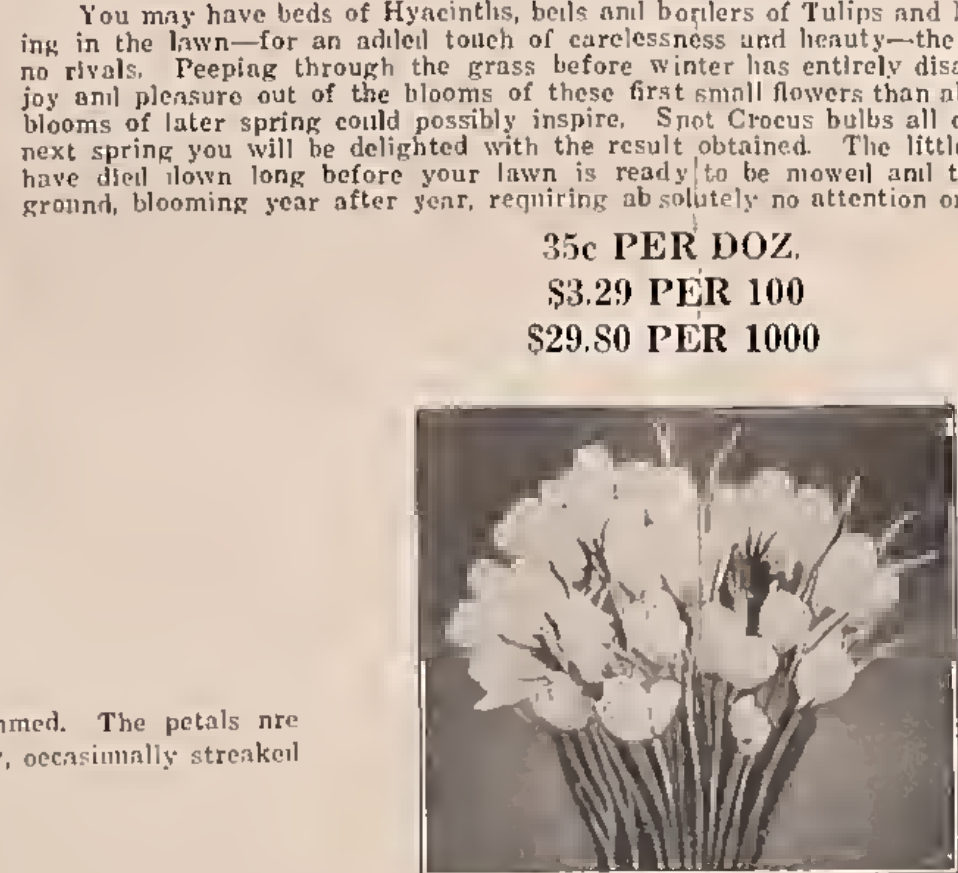

DARWINS IN ASSORTMENT
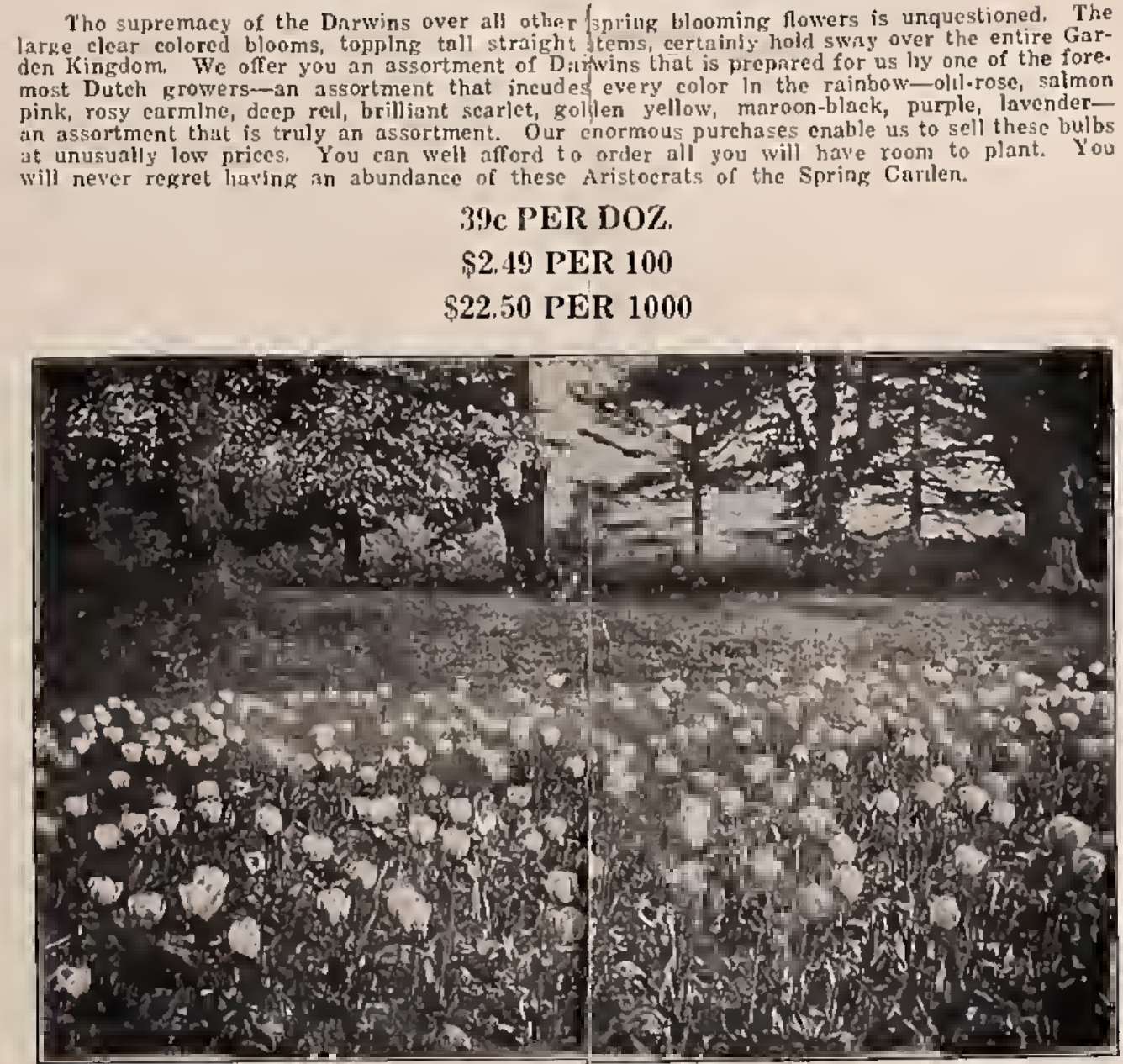

Groun lination

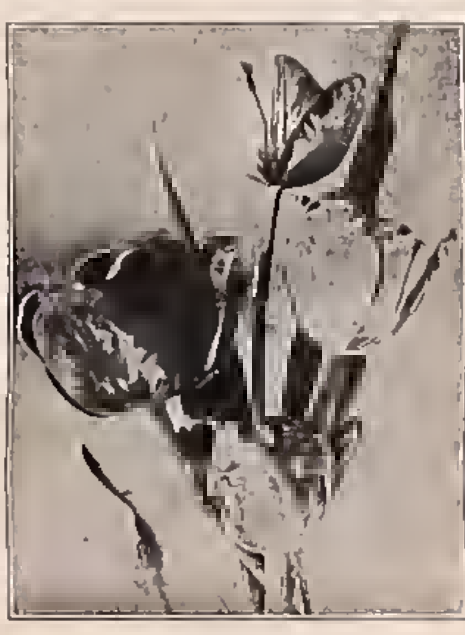

69c PER DOZ $\$ 4.69$ PER 100 $\$ 43,50$ PER 1000

LARGE SIZE FORCING HYACINTHS
$\$ 2.98$ PER DOZ,
$\$ 19.65$ PER 100
$\$ 169.50$ PER 1000

HYACINTHS

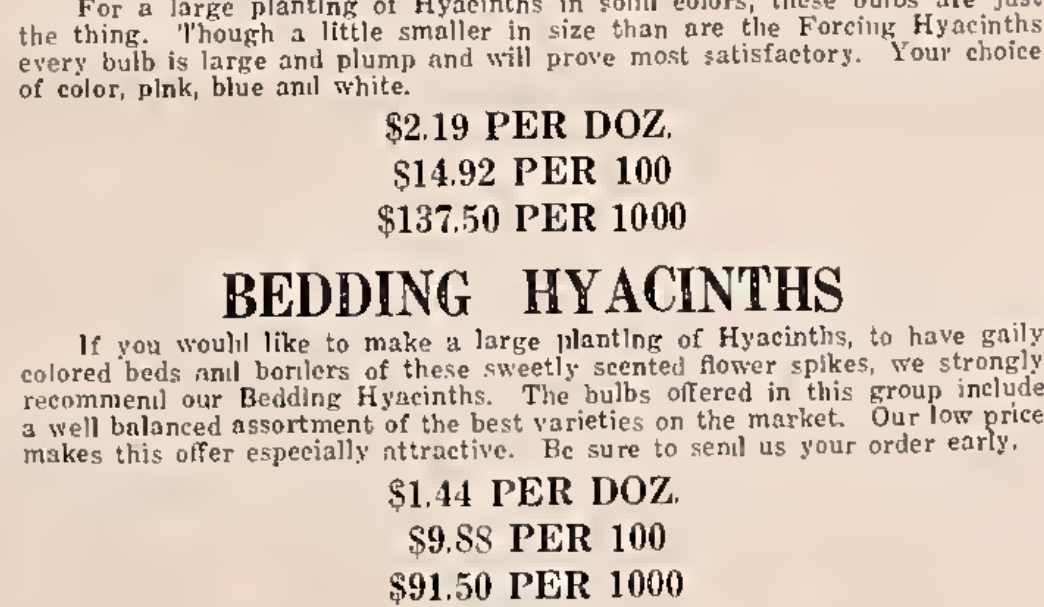

EARLY DOUBLE TULIPS

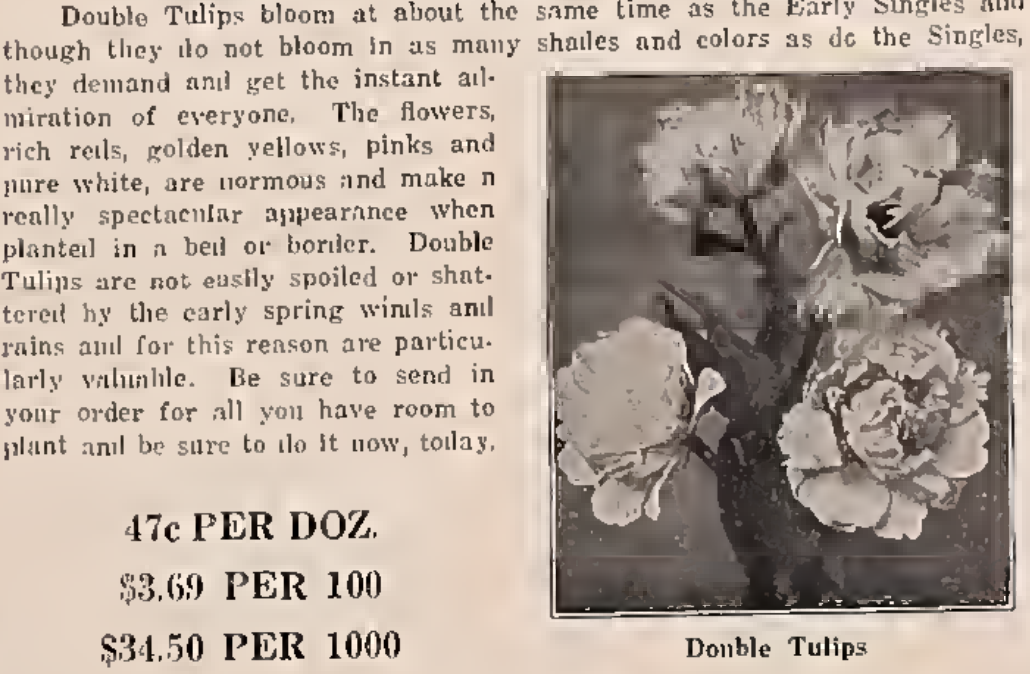

Growers' Sales Company
GIANT CROCUS 


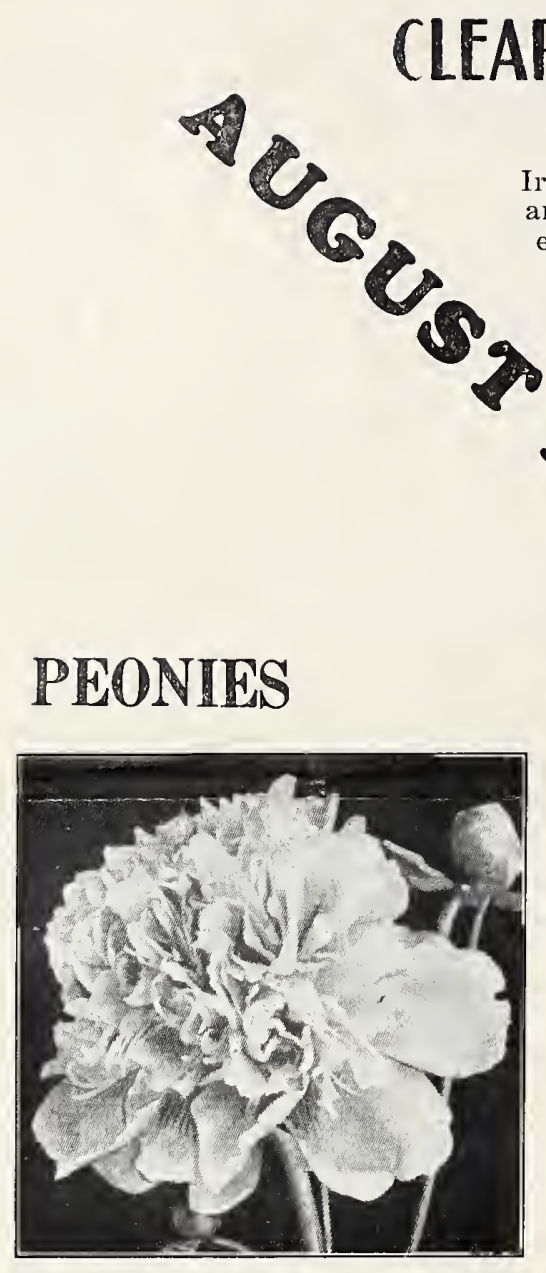

3 For Only $\$ 1.00$

\section{COREOPSIS}

We have an enormous block of improved Coreopsis on which we will make a big August Special at $\$ 1.10$ per dozen. Coreopsis are a rich golden yellow without a trace of any other color. A dozen plants will produce hundreds of blooms in a single season as they bloom continuously from June until October. Here is both quantity and quality. Regular price $\$ 2.50$ per dozen. At our Special August price of $\$ 1.10$ per dozen you should order all you have room to plant. Do it Now.

12 for $\$ 1.10$

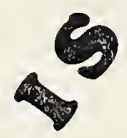

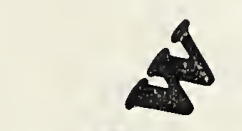

We will have a limited supply of fine three to five eye Peony roots which we can offer at 3 for $\$ 1$ for early fall delivery so as to have them all sold in advance of digging time in September. If you want some very fine $\mathrm{P}$ e on $\mathrm{y}$ roots, here they are and at a figure $\mathrm{you}$ cannot duplicate.

of Garden Iris

Irises, blooming in royal purple, powder blue, rich blue, yellow, bronze por rare beauty and perfection. For rock gardens and border anting they are indispensable. Even when the flowers are not nill will dark green spear-like leaves are decorative grounds. In order to make a complete clearance of e block of this fine Garden Iris so that we may these beautiful Irises for only $\$ 1.00$.
the

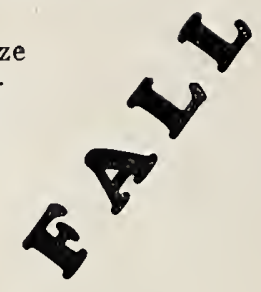

20 For Only $\$ 1.00$
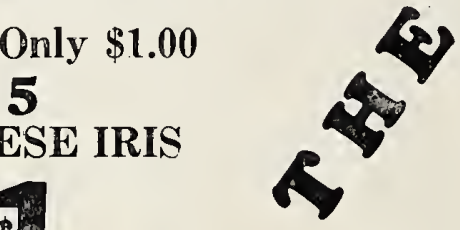